\title{
Across Bangalore
}

\author{
Sherry Simon
}

Lakshmi enseigne le sanskrit; je suis venue ici pour enseigner le français. Nous faisons un pacte secret, s'abandonnant à un désir commun: parcourir les chemins de notre similitude, surmonter les coups durs de notre différence, connaître tout du monde de l'autre.

He said to me once that one could never know anything except through desire, real desire, which was not the same thing as greed or lust; a pure, painful and primitive desire, a longing for everything that was not in oneself, a torment of the flesh, that carried one beyond the limits of one's mind to other times and other places, and even, if one was lucky, to a place where there was no border between oneself and one's image in the mirror.

-Amitav Ghosh, The Shadow Lines

Crossing the city could take more than an hour, and each of those moments in a rickshaw meant lungfuls of diesel exhaust, sudden swerves and painful bumps, so whenever either Lakshmi or I crossed the city to see each other the very fact of the visit was already a huge debt incurred. Each treated the traveler with the respect due to one who has just undertaken a perilous journey, immediately offering water and a cool place to recover from dust, heat and the rickshaw - "auto," it was often called, the automated version of the human-runner kind, of course an immense improvement, but still a source of indignity, both to driver and passenger, a three-wheeled scooter with a passenger seat and hood added, not much in the way of suspension and so rebounding off every crack and swell in the pavement, open to dust, waves of water in the rainy season, and no real power or speed, the lowest in the hierarchy of vehicles on the streets of India, except for the bullock and the bicycle, always beeped at and overtaken by scooters and motorcycles, cars, buses and trucks.

I lived in Malleswaram, a neighbourhood in the north end of the city, and she in Bashenkar, in the very south end, and these were not the only two extremes which marked the difference of our coming together, but they marked the difficulties of our encounters surely as much as the others, the divide of place from which we came.

Yet across that divide ran the strips of our same, some of which counted 
and others that didn't, categories that fell into alignment, her family in perfect symmetry with mine, her job too, a life in a river of many languages and the songs she sang with her daughter.

Lakshmi teaches Sanskrit, I have come here to teach French. We meet at the university where we are office neighbours, and our families get together for Sunday breakfast in the Tiffin Room, a restaurant a block away from the Botanical Gardens, where they serve breakfasts of buttery dosa and sticky ghulab jamoon to families crowding around large tables. To hear each other we have to shout, and so it is a relief to get out into the morning sun and stroll through the gardens, the men pairing off, the children forming a cheerful bunch, and the two of us falling behind the rest, my pale spareness beside her black and gold sari, and together paying only cursory attention to the mildewed pavillions of the Gardens, caught up rather by the spectacle of lithe, shy newlyweds who are taking their first Sunday strolls together.

We strike a silent pact, surrendering to a common desire: to navigate the veins of our sameness, to clamber over the raw accidents of our difference, to know everything about each other's world.

Instead of meeting at the university which is a collection of new brick squares plunked down outside the city, Lakshmi and I decide to explore the city together, spending mornings at Russell market, watching the Muslim artisans make cane furniture, shuddering at the hunks of meat hidden in the back corner of the market, lingering at the mounds of cut flowers and choosing armfuls of irises to take home. Other days we go downtown to the bookstores, soon ducking into a restaurant for a biryani or a coffee.

But we tire of these excursions in the heat and prefer to see each other in the quiet of home. When the pace of our conversations starts to let up and we have finished tracing out the crazy path that connects a Tamil village to a European stetl, completed our study of childhood smells (and some are the same, chalk and blackboard), remembered the same dreamy years when novels were life (only she was curled up in a hammock in the shade of the leafy garden, flies in her hair, and I was on the corduroy sofa by the TV), once we have drawn up the lists of our favourite books and argued long and hard about the shortcomings of Western theory, we decide that it is time for us to work on a project together. We decide to translate a story. There's a Tamil story by a popular author that she's particularly fond of. She'll give me a literal version of the Tamil as we go along, we'll work out the English together and then I'll put it into French.

It's a story about a woman named Durga, a story without much plot, more like a portrait drawn with quick and untidy strokes. I find the story ragged, its sentences so loosely strung together that it feels like it will fall 
apart any time. Lakshmi, however, follows each thread with attention and respect, giving heed to every detail.

I can see that Lakshmi identifies with the heroine. Durga is an "ordinary" woman, says the first sentence, but only apparently so, really she is a free spirit, the very force of life. On the marriage night of their daughter, Durga and her husband are sitting outside in the warm night and she thinks back to her own wedding, remembering how hopeful she and her husband were. A young filmmaker has now fallen in love with her. She is tempted by his love, but decides to remain faithful to her husband.

Lakshmi and I are sitting on the floor side by side, the book of short stories on her knees, my laptop on mine. We sometimes argue for quite a while over a word, the "ordinary" of the first sentence, for instance, takes ages to find, because the writer had phrased his sentence in the negative. "She was not a special person", he said, but of course we know that she is, and want a better way of marking the irony of the introduction. Lakshmi's knowledge of English is precise and mine feels rusty in comparison, as if English were my second language rather than my first.

Her patience lasts longer than mine. She is consumed by the story, and loves caressing the grain of Tamil, a language she learned late. She reads each sentence and then comes up with a few sentences of English, moving around and then closer to the meaning she's looking for. Then there is room for my voice, questioning and rephrasing, wondering how much I can quietly push the story away from the attitudes I disapprove of: the filmmaker wants to "take possession" of Durga, her smile remains "mysterious" and "wise." I don't like these set poses, the bits that sound too familiar to me.

I can visualize some of the events of the story, filling in the storyteller's silences with the bits of Indian culture I have begun to acquire. I see a semi-rural setting, huge leafy trees around a dark house and the benches where Durga and her husband fall asleep in the summer warmth, side by side, after the wedding festivities. Now that I've been to some Indian weddings I note the satisfaction and relief of the parents, and also their comfortable sensuality, the way they are at the same time distant and companionable. I put Durga in a gold-bordered wedding sari for this special evening, her husband in a Western shirt and silk dhoti. I also see the ox-blood concrete floors and crumbling green paint of the office where he works, the piles of ledgers, the cups of coffee carried in by the young messenger-boy at exactly 10 in the morning.

There are other parts of the story I don't really understand. Did Durga's husband give in to corruption or not? Lakshmi doesn't want to discuss the husband; she's much more interested in Durga. I too find myself aspirated by one of the characters. If Lakshmi is Durga, I am the filmmaker who 
melts under Durga's gaze, who is made agonizingly aware of the "driness" of his work by those eyes, who, when he speaks of loving her receives the response: "Do..."

When lunchtime comes, Lakshmi heats up some of the food she's prepared before breakfast, always rice and a vegetable dish, yogourt and pickle, sometimes chappatis or maybe a special dessert, a feast that is first offered and then pressed upon the guest, what would you like followed by what you must have, a bit of this or that, always the same ritual words, the warm voice and insistent phrases as much a part of the meal as the metal vessels. We sit on the kitchen floor, the coolness of the hard surface under our crossed legs, me trying to learn to eat correctly with my fingers.

Working through the afternoon is slower going. I want to rest my head in Lakshmi's wide lap, feel my cheek against her round arm. I can smell the coconut oil in her hair, and see the thickness of each strand of long black hair stretched tightly away from her face and then exploding in an exuberant spray down her back.

Lakshmi is the best kind of translator. She's in no rush to interpret each sentence, or criticize the writer for not being more precise. It's her attentive nature that speaks here, her loyalty too. There is no question for her about which side of the cultural divide she belongs to. Her real love is for the Tamil language and for this place. She is not a traveller, not an adventurer. The few times she travelled abroad she was miserable with longing for home and cut her stay short.

Lakshmi was right to provide herself with a quick ticket home. She was not about to lose her points of reference, fall into any third spaces, get dizzy with the incessant comings and goings that unsettle familiar boundaries forever. Translators can easily get lost when they stay away too long, when they try to learn too much about the world on the other side of their language borders. She would never allow the frame that defined her reality to loosen, to become a lumpy, leaking thing.

When our sessions are over, we stroll over to the busy intersection to get a rickshaw. I don't usually stay for supper-that would mean a ride home in the dark by myself. Everybody says this is dangerous, and I had a taste of it when once I challenged local wisdom and got a rickshaw driver who took a totally unfamiliar route home, stopping several times for gas, oil, and betel, each time taking time to chat and not paying any attention to me. In the vast and black Bangalore night the city is a stranger. There are neither lights nor friends to count on, only the headlights of passing vehicles that give gray substance to the oceans of exhaust that rise like floodwater over the main boulevards, only a few street lights, signalling here and there a familiar sight, but mostly waving you into the black mystery 
of a jumbled city, a labyrinth which defies maps, and you could be led anywhere.

When I arrive back at our apartment at night the watchman is lying across the front step, asleep in a blanket and woolen cap. The obstacle of his body is guarding our building, one of the concrete high-rises filling my neighbourhood, Malleswaram, one of the oldest parts of Bangalore. The new buildings are interrupted here and there by the old houses, low, with Turkish-looking decorative wooden gables set back among groves of noble flowering trees. All these constructions are set at awkward angles to one another, never lining up obediently along the street, many of them now owned by Indians abroad.

I like my busy, noisy street, the boys playing cricket in the tiny courtyard every afternoon, the rheumy sunset from the balcony, the red glow darkened by layers of gray dust. All day the clamour of traffic climbs and lashes at my closed windows, from the early-morning ring of a solitary bicycle bell to the scream of horns that comes at peak hours, meek tooting from the little vehicles and get-out-of-the-way-otherwise-you'll-be-dead blasts from the trucks and buses, and added to the commotion of the street is the clatter of vessels being washed on the balconies and the high-pitched conversations on the landings, but when I walk to the market the sidestreets are quiet and the floppy leaves wave at me as I pass. Sometimes I linger on the sidewalk to watch women buying batches of mangoes for pickles or a shoemaker setting up for work on the sidewalk, sharpening his tools and sending his son to get him a package of betel before he begins. When I get home I prepare a salad of silver pineapple, amber mango and papaya the colour of flame.

Lakshmi and I decide to interview the author of the short story to collect material for the preface we'll write. We have to go over to a part of town I don't know, a pleasant residential area where the streets are lined with gulmohurs and ashokas. To get there we take the bus and, once we've battled our way onto the fat red giant (miles taller than the poor rickshaw), I watch the traffic scatter as we careen and hurtle ahead.

The author has a fleshy round face, a neat moustache and a magnificent smile which he mostly directs at Lakshmi during our long talk. He is wearing modest white pyjamas, and quite evidently enjoys the attention we are giving him. He is alternately hopeful and angry, explaining how important modernist ideas are for Tamil writing, dismissing the airy-fairy idealism of "Ford-funded intellectuals", describing his relationship to Western literature and to the ancient traditions of Tamil. He writes his own stories in the local language, and has no dream of a vast English-speaking readership, preferring to modernize his own tradition, work against the con- 
servative forces that drive writing towards folklore and entertainment.

Lakshmi is incisive, phrasing her questions knowledgeably, smiling encouragement, and continuously complimenting the author, showing the deference which I see is a sophisticated form of flirting. Lakshmi comes to life in this kind of conversation, thinking out her ideas in response to the author's musings, displaying the gifts that make her the excellent translator that she is, knowing how to go poking about in someone else's ideas and still find her way home. I enjoy the sturdiness of her back as she moves her gaze from the author to me and back again. She will never topple over into confusion...

The author explains how he uses translation to nourish his own writing, taking as his own the words of other writers. These outside voices, he says, lead him to discover new voices within himself. Cultural border guards are easily outsmarted, he boasts. I see that he and Lakshmi both think of translation as a quick dash over the border-the escapade of a clever smuggler. They're prepared to use whatever cultural goods will serve their purposes, using translation as a knife to scratch off the sticky label of origin.

Lakshmi and I are supposed to be conducting the interview together, and she is careful not to fall into Tamil with the author, but I feel increasingly uncertain as the afternoon goes on, my body even more pale and insubstantial than usual, my voice thin and lacking in conviction. Very little of what I know seems to be appropriate here and I'm uncomfortable trying to stay sitting cross-legged. There's not much of the intrepid explorer left in me.

My visit to India seems to be lasting too long. My family has gone back now, leaving me to finish my work, but every day I forget a bit more of the life I had at home, and why I had to do and know the things I did. I have joined that legion of travellers who are singed by the heat of India, who become heady and dazed by its dissonances. I'm beginning to see myself as a piece of debris which has just happened to wash up onto land, like the dolphin I saw on the beach in Trivandrum, its naked jawbone jutting into the air, each wave sucking bits of rotten flesh off the carcass, licking the cockeyed mass into shudders of shame.

I make an effort to propel myself back into the interview and justify my presence here. I try to get the author to question what he means by his "own" culture. Didn't he know that the novel form was imported into Indian languages, that the first "Indian" novels were modelled after translated works? Isn't he aware that his writing must in some ways follow Western influences? The author senses the provocation and he responds with his own questions. What about the Indian tradition of storytelling? Hasn't this tradition influenced Western narrative? And, anyway, what's 
the point of trying to win at the game of origins? If you can't separate idea from influence, translation from writing, is this a problem?

The author's companion, his second wife, has been listening respectfully to the whole interview, monitoring, I suspect, his interaction with Lakshmi. She makes no comments until she produces hot fried snacks and coffee, introducing soft eddies of food-talk into the potentially dangerous waters of our conversation.

By the time we leave the author's house it is dusk and Lakshmi and I are too tired to fight our way onto a bus. We stroll down the main street, enjoying the gentle evening air despite the hot breath of exhaust fumes. I insist on buying Lakshmi the plump brown breadfruit that she loves, far too mushy and sweet for my taste. We walk arm in arm, and I look affectionately at the groups of young boys loosely holding hands or slinging their arms around each others' shoulders. I admire the relaxed competent gait of the women completing their shopping. When we walk by a market we buy jasmine petals for our hair and I spend the rest of the evening lost in their perfume.

Tonight I give up on finding my way back to my part of town, and sleep in Lakshmi's house. Lying under my mosquito net, I listen to the soft breathing coming from beds placed here and there in the small apartment, the elderly parents in the next room, the children sleeping on cots in the hallway. I can guess the shape of Lakshmi's body, the grain of her skin in her warm night bed. I wonder if these firm surfaces are not deflecting me away from a more untidy story, if the geographies of daylight don't disappear for her too when the city turns black.

In my diary, I write the dates with increasing awe as the day of my departure approaches. It has been some weeks now since I saw my family off at the airport. By the time they left it was two in the morning and I was rushed back across the city in the hired car, the streets deserted, the driver seeming to have no thought for the bullock cart or bicycle that might be waiting around the bend as he sped through each roundabout, giving me my revenge on the hectic city, on the press of traffic and the confusion of tiny streets. The airport was behind me, the heat and mosquitoes, the large crowds of family casting their final impress on the traveller. It was cool and fragrant in the car, and I was small on its springy seat, a fragment in this city where no one is alone.

The rainy season has begun, the trees shaking with surprise as the cold air suddenly chases the warm and slowly, very slowly, the hot air long trapped in the apartment is forced to renew itself. Children on the street shriek with joy as the first drops of rain arrive, but I'm wondering about the shanty town on the edge of the railway tracks. Those children will be 
sleeping in mud, slogging along water-soaked paths, and smelling the newly virulent trash.

The power cuts are getting longer and longer, despite the promise of renewed water reserves. The huge cockroach I've gotten used to seeing around the kitchen turns up dead in the fridge, drowned in sog from the melting freezer compartment. I've become used to feeling absent, a nonresident in my body. I have become lighter during my stay here, the burden of identity considerably lessened, not contained by language either but open to the airy currents of estrangement. It's as if I've exchanged the weight of selfhood for the surfaces of skin and fabric, the shell a reassuring foil for the absent kernel, the sound of words sufficient points of contact.

The teaching term is ending at the university and I have been told that I must administer oral exams to the students in my French course. I'm not quite certain why any of the students want to learn this language. French is simply one more note in the thickly textured dissonance of idioms here, the Kannada, Hindi, Tamil, Telugu that you hear on the streets, not a triumphant language but an idiom of defeat, just like at home, the colonies in Canada and India handed over under the same Treaty of Paris to the doubly victorious British, and so French makes no pretense to rivalling English, offering itself as a curiosity and the key to no particular door.

It's Usha's turn today. She's wearing jeans, one of the very few women students who doesn't wear saris. She's too thin, but her black eyes flash as she makes an impassioned and precise speech on the virtues of yoga. She does away with Western illusions in a few lapidary formulations. Romantic love, she says, is "as egoistical as it is ephemeral". She will never, evidently, have any truck with such Western nonsense. Adoringly, she paints the landscape of yogic ideas and practices. I want to follow her there, walk barefoot along the paths of conviction, breathe in serenity with the perfume of the jackpines.

Upamanyu, a gentle slim boy, is equally self-assured in his little speech. But he surprises me with his anger. He has chosen to talk about the movie $M$ Butterfly. It's about a French diplomat working in Peking who falls in love with a Chinese opera singer. The singer turns out to be a transvestite and a spy, and the diplomat is sent to jail. Upamanyu sees an exhilarating lesson here. Finally, he says, a movie that shows how cultural ignorance will lead to the downfall of Western civilization. The diplomat should have known that the women's roles in Chinese opera are always played by men. If he had known more about Chinese culture, he would have understood that he was being tricked. I try to argue with him, suddenly feeling intense sympathy for this diplomat who lost his cultural bearings and fell for the wrong object, this man for whom cultural confusion was the beginning of love. Upamanyu listens politely to 
my arguments but shows no indulgence.

Lakshmi and I rush to finish our story, using every minute we can together. We disagree about how the story is to end, the last sentence involving a subtle difference between "going" and "coming" home which I have difficulty understanding, and even more difficulty finding a French equivalent for. Probably I'll have to shift the emphasis away from the verbs of movement to words for home, so Durga will be returning dans son foyer, dans sa famille, chez elle or à la maison, the sequence of those terms indicating an ever thinner attachment to that place and that part of her identity.

Though my translation is now virtually complete I'm not at all sure of it. Lakshmi showed it to a colleague from France who found some of the French expressions awkward, and I sense that she has lost her confidence in me, wondering if all these hours have been wasted.

I'm not surprised that my text doesn't stand up to scrutiny. The task of the translator is to to be a beacon guiding the text across the divides of difference. How can I do this when I have lost my own bearings in this cluttered city of words? It's true, as Lakshmi has told me, that every language focuses on some central point of being, here rather than there, home rather than away, one fixed and settled point to go away from and come back to and which permits the proper use of verbs of movement, of adverbs of location. Once you lose that point, you begin to stumble along muddy sidewalks that somehow all look the same, the line of horizon a dirty smudge against the pale sun.

When I leave Lakshmi's flat for the last time, both of us know that I have failed. I have not been what she wanted, someone who was as strong in my place as she is in hers. Instead I have allowed the confusions of this place to enter the cracks of my being, force them wide open and crumble me bit by bit. Lakshmi walks me to the corner even though it's raining hard. Finding a rickshaw tonight is more difficult than usual. The intersections are awash in water, the traffic nervous, rickshaws and scooters squashed into a dense pack moving jerkily forward, thrumming ahead whenever there is the tiniest space. The line of drivers presses against the tyranny of the red light, revving their motors, waiting to pounce as soon as the signal comes. Scooter passengers hold umbrellas in their free hands, and the black canopies are a ragged roof over the angry swarm.

As I step into the rickshaw, Lakshi begins a hurried speech of affection, offering wishes for my speedy return, but the words ring false and I turn away before she's finished. Splashing and lurching homewards, I suck in the damp gray air around me, coating my insides with the gritty memory of this place. 